\title{
Quantification of strain rate in the Western Alps using geodesy: comparisons with seismotectonics
}

\author{
Bastien Delacou ${ }^{1}$, Christian Sue ${ }^{2, *}$, Jean-Mathieu Nocquet ${ }^{3}$, Jean-Daniel Champagnac $^{4}$, \\ CÉCIle Allanic ${ }^{1} \&$ Martin BurkHard ${ }^{1 \dagger}$
}

Key words: Western Alps, GPS, geodesy, strain measurement, seismotectonics, geodynamics, extension, strike-slip, rotation

\begin{abstract}
The contrasted seismotectonic regime of the Western Alps is characterized by radial extension in the high chain, combined with local compressive areas at the foothill of the belt, and everywhere occurrence of transcurrent tectonics. Here, we compare this seismotectonic regime to a large-scale compilation of GPS measurements in the Western Alpine realm. Our analysis is based on the raw GPS database, which give the measured velocity field with respect to the so called "stable Europe", and an interpolated velocity field, in order to smooth the database on a more regular mesh. Both strain rate and rotational components of the deformation are investigated. The strain rate field shows patch-like structure, with extensional areas located in the core and to the North of the belt and compressional areas located in its periphery. Although the GPS deformation fields (both raw and interpolated) are more
\end{abstract}

spatially variable than the seismotectonic field, a good qualitative correlation is established with the seismotectonic regionalization of the deformation. The rotation rate fields (both raw and interpolated) present counterclockwise rotations in the innermost part of the belt and a surprising continuous zone of clockwise rotations following the arc-shape geometry of the Western Alps along their external border. We interpret this new result in term of a counterclockwise rotation of the Apulia plate with respect to the stable Europe. This tectonic scheme may induce clockwise rotations of crustal block along the large strike-slip fault system, which runs in the outer part of the belt, from the Rhône-Simplon fault to the Belledonne fault and Southeastward, to the High-Durance and Argentera fault.

\section{Introduction and current seismotectonic setting}

Seismotectonic studies have shown the contrasted strain/stress seismic fields across the Western Alps, with the occurrence of both extensional and compressional regimes (Fig. 1, modified after the review of Delacou et al., 2004; see also Ménard 1988; Eva \& Solarino 1998; Sue et al. 1999; Baroux et al. 2001; Kastrup et al. 2004). In this paper, we make a new analysis of the published geodetic velocity in order to study the orogen-scale deformation of the Western Alps (Nocquet 2002; Nocquet \& Calais, 2003; Nocquet \& Calais, 2004). The strain rates associated to surface GPS velocities are precisely compared with seismotectonic data to test the consistency of each techniques when applied to the regional deformation analysis across the belt. Moreover, GPS-derived strain rates (despite their limitations in accurately measuring small velocities) provide a quantitative assessment for the study of strain rates on the scale of the whole Western Alpine Arc. GPS measurements show slow to very slow surface velocities around the bend of the Western Alps (e.g. Caporali \& Martin, 2000; Oldow et al. 2002; Serpelloni et al. 2005). GPS velocities are estimated 3 to $5 \mathrm{~mm} . \mathrm{y}^{-1}$ on the period 1995-1998, and decrease with the duration of measurements (Calais 1999; Calais et al. 2000; Vigny et al. 2002). Some local/regional quantifications of GPS deformation show velocities of about 2 to $4 \mathrm{~mm}^{-\mathrm{y}^{-1}}$ of E-W oriented extension in the Brianconnais area (Sue et al. 2000), 3 to $5 \mathrm{~mm} . \mathrm{y}^{-1}$ of compression/strike-slip deformation in the area of the front of Belledonne massif (Martinod et al.1996; Martinod et al.2001) and 5 mm. $\mathrm{y}^{-1}$ of E-W to NE-SW compression at the southern termination of the Jura (Jouanne et al. 1994). The first permanent GPS stations were installed in the late 1990's. Using 3-4 years dataset, Calais et al. (2002) and Nocquet \& Calais (2003) proposed an upper limit of $0.5 \mathrm{~mm} \cdot \mathrm{y}^{-1}$

\footnotetext{
${ }^{1}$ Institut de Géologie et d'Hydrogéologie, Université de Neuchâtel, Switzerland.

2 IUEM, Université de Brest, UMR 6538/UEB France.

${ }^{3}$ Géosciences Azur, CNRS-Université de Nice-Sophia Antipolis, France.

${ }^{4}$ Geologisches Institut, ETH-Zürich, Switzerland. Now at Institute of Mineralogy, University of Hannover, Germany.

*Corresponding author: Christian Sue, IUEM/UMR 6538, Place N. Copernic, F-29810 Plouzané, France.E-mail: christian.sue@univ-brest.fr
} 


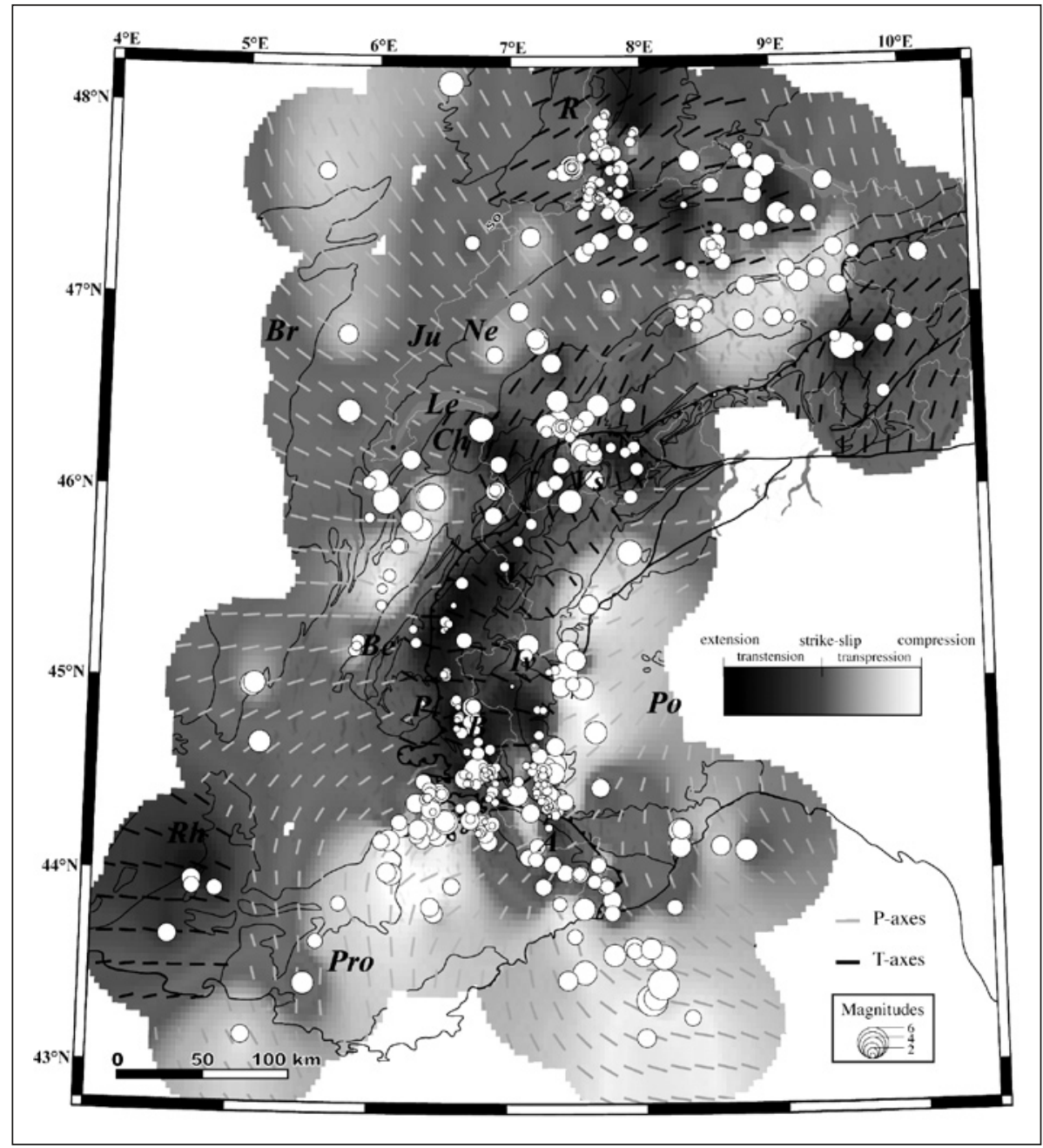

Fig. 1. Seismotectonic map of the Western Alps showing the earthquake locations and the tectonic modes derived from the focal mechanisms, with extension in black in the core of the belt (the so-called high-chain) and compression in white in its periphery (see color version in Delacou et al. 2004)

Localization of sites quoted in the text: A: Argentera massif, B: Briançonnais, Be: Belledonne massif, Br: Bresse, Ch: Chablais, Ge: Genova bay, Iv: Ivrea Zone, Ju: Jura arc, Le: Leman Lake, MC: French Massif Central, Ne: Neuchâtel Lake, P: Pelvoux massif, Po: Pô plain, Pro: Provence, R: Rhine graben, Rh: Rhone valley, V: Vanoise, Vs: Valais. for the relative extensional velocity between the two sides of the orogen (Lyon and Torino), and of 1 to $2 \mathrm{~mm} \cdot \mathrm{y}^{-1}$ within the Alpine belt itself. Similarly, Walpersdorf et al. (2006) using semipermanent GP measurements found an upper limit of $1 \mathrm{~mm} . \mathrm{y}^{-1}$ for the deformation accommodated in the Jura mountain range. In the present study, we present an homogeneous large-scale analysis of the GPS velocity field across the whole Western Alps. In the light of recent seismotectonic studies, we propose a tectonic scenario for the complex active geodynamics of this part of the belt, where plate tectonics (rotation) and buoyancy forces (extension) interact.

\section{GPS velocity field}

This study concerns the whole Western Alps and its forelands, and is based on the most reliable GPS-related velocity field currently available for the area (Fig. 2 after Nocquet 2002; Nocquet \& Calais 2004; see also Tesauro et al. 2005). The velocity field is derived from the combination of previously published GPS data acquired in both permanent and campaign mode. The continental-scale solution of Nocquet \& Calais (2003), including 64 permanent sites in Western Europe, is used as a backbone for the velocity field. It showed that Central Europe behaves rigidly and defines a stable Europe reference frame, in which the current strain pattern in the Western Alps combines an E-W extension with a right-lateral shear. This solution is then improved using data from 23 sites of the French Geodetic Reference Network (RRF) observed in 1993 and 1996 (Boucher et al. 1998) and the GPS-Alps network acquired between 1993 and 1998, including 70 sites in the Western Alps, with an averaged inter-distance of $\sim 50 \mathrm{~km}$ (Vigny et al. 2002). A few sites of the Alpine network and the Rhine graben were re-measured in 2000 and 2001. In our approach we use the methodology described in Altamimi et al. (2002), which applies reference frame constraints simultaneously for all individual solutions. The consistency of the final solution is ensured through common reference sites. Local ties between permanent and campaign markers were included in the analysis when available. Otherwise, a velocity equality constraint was imposed between permanent sites and campaign sites closer than $5 \mathrm{~km}$. Nocquet

378 B. Delacou et al. 
(2002) showed that these additional constraints transmit part of the accuracy provided by permanent measurement over an influence circle of $\sim 50 \mathrm{~km}$ radius.

The resulting final velocity field has an accuracy of the order of $2 \mathrm{~mm} . \mathrm{y}^{-1}$ (95\% confidence level, slightly better for permanent GPS sites); so individual pair of sites can only resolve strain rate larger than $4.10^{-8} \mathrm{y}^{-1}$. In order to permit tectonic interpretations, velocities are expressed with respect to "stable" Europe, defined by a subset of sites located in Central Europe with internal velocities lower than $0.4 \mathrm{~mm}$. $\mathrm{y}^{-1}$ (Nocquet 2002).

\section{Methods of strain quantifications}

In order to quantify the strain field associated with the measured GPS velocities, we calculate the velocity gradient tensor in triangular cells, defined by 3 proximate velocities (tri- angular velocity basis). This matrix, so-called $\mathrm{D}$, is classically decomposed in 2 matrixes: a symmetric matrix for the strain rate tensor $\mathrm{S}$ and a rotation matrix for the rigid rotation rate $\mathrm{R}$. The symmetric strain rate tensor can be diagonalized and the associated eigenvalues $S_{1}$ and $S_{2}$ correspond to the maximum shortening and stretching rates. The sum of these two eigenvalues defines the dilatation rate (Fig. 3). The negative values correspond to a compressional regime and the positive values to an extensional regime. The rotation matrix $\mathrm{R}$ defines the rigid rotation angle $\omega$ (Fig. 4) corresponding to the rotation of the triangular basis. The negative values refer to a clockwise rotation and the positives for an anticlockwise rotation. Strain rates are expressed in $\mathrm{y}^{-1}$ and rotation rates in rad. $\mathrm{y}^{-1}$. For tectonic interpretation purposes, one should keep in mind that $2 \cdot 10^{-8} \mathrm{y}^{-1}$ correspond to a $1 \mathrm{~mm} \cdot \mathrm{y}^{-1}$ strain, for a typical baseline of $50 \mathrm{~km}$, and that $2 \cdot 10^{-8}$ rad. $\mathrm{y}^{-1}$ corresponds to 1,15 degrees/My. However, in the following sections, we will present our results of the

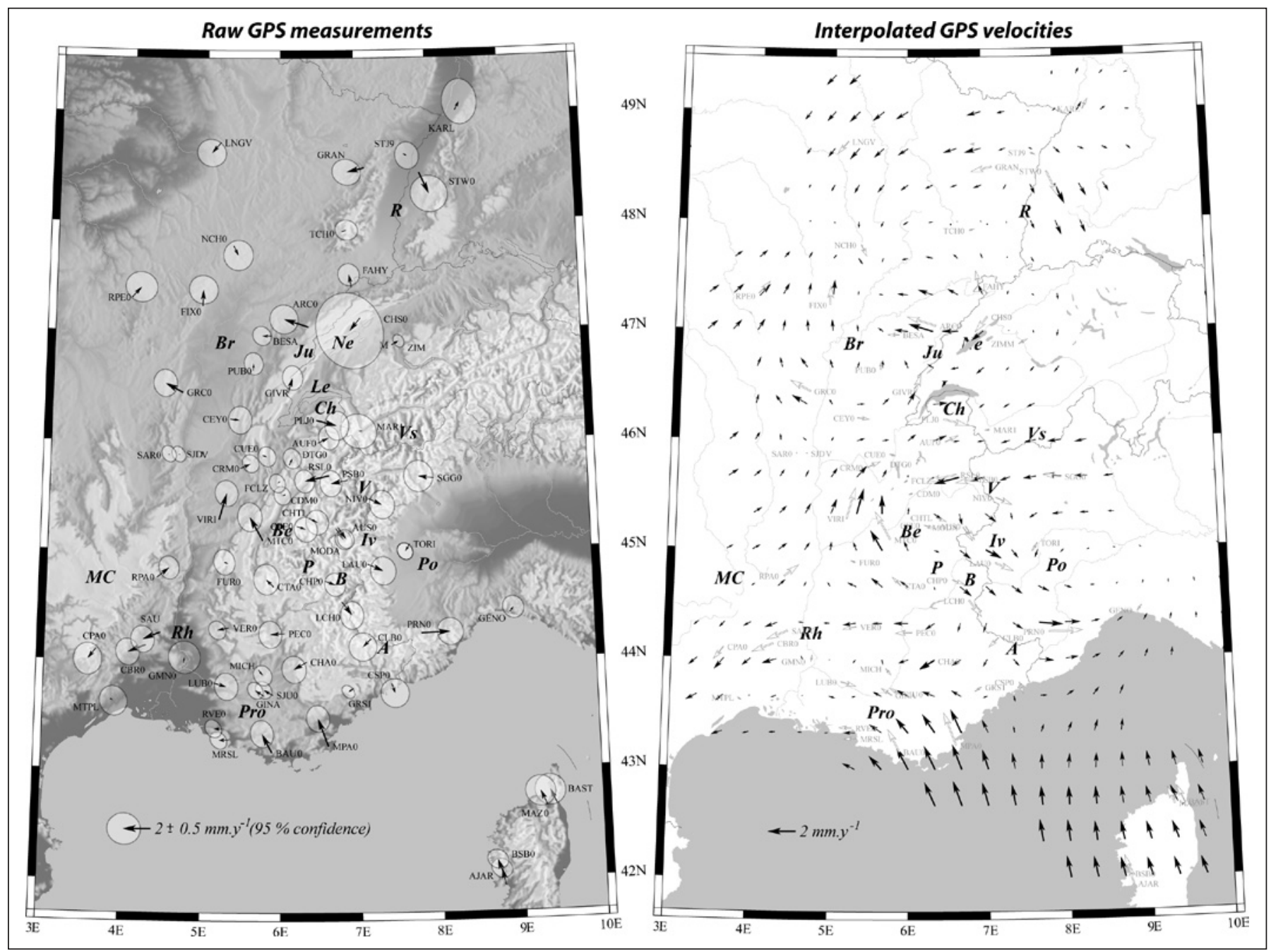

Fig. 2. GPS velocity field of the Western Alps (database in Nocquet 2002). Left: raw data; right: interpolated velocity field (see text for details). Velocities are defined with respect to stable Europe, together with their $95 \%$ confidence ellipse, and the name of the GPS stations.

Abbreviations: see Fig. 1. 
strain quantifications in $\mathrm{y}^{-1}$ and rad. $\mathrm{y}^{-1}$, emphasing the fact that these rates are not scale-dependent.

One of the main problems encountered in this type of computation is related to the geometry of the triangular velocity basis chosen. An inadequate triangular geometry can average out a contrasted deformation, since a priori variations of wavelengths of deformation regime are unknown. For instance, if the triangles are too large, compressional and extensional deformations can cancel each other within a triangle. This gives an incorrect image of the deformation regime, leading to a meaningless quantification. In fact, the seismotectonic regime (Fig. 1) displays short wavelength variations for the deformation regime in the alpine chain and its forelands (in both modes and directions of deformation). These variations are smaller than the density of the GPS network used in this study. Such GPS measurements, in spite of an increasing densification in the last 10 years, still present an insufficient sampling of the deformation. We should keep in mind that the strain and rotation rates derived from GPS measurements correspond to the values integrated over the triangle areas and therefore are likely to underestimate actual local values for the deformation rates. Indeed, the GPS-derived strain quantification is relevant only for the integrated strain within a given triangular cell, and could not discriminate strain variations inside the cell.

In the following section, we present two different triangular meshing techniques on the computation of deformation rates, in order to detect smaller wavelengths in the deformation field.

\subsection{Strain rate field derived from the raw GPS velocity field (Fig. 3a, 4a)}

On the basis of GPS station position and associate velocities (Fig. 2a), a triangular mesh is established (called raw GPS basis) for the calculation of strain and rotation rates (Fig. 3a and Fig. $3 \mathrm{~b}$ respectively). In order to reduce the under-sampling of strain rates, we manually designed the interconnection between the GPS stations, which define the triangular basis, reducing their area as much as possible.

\subsection{Strain rate field derived from the interpolated GPS velocity field (Fig. 3b, 4b)}

Alternatively, we perform an interpolation of the GPS velocity field (Fig. 2b) on a regular grid every 20' (corresponding to $25 \mathrm{~km}$ in longitude and $37 \mathrm{~km}$ in latitude). The main advantage of this technique is to smooth the velocity field. Thus, random errors occurring on individual sites are reduced and the major trends on strain rate patterns are enhanced. Our interpolation assumes a continuous velocity field and does not consider the effects of possible fault-related velocity discontinuities. However, active faults are sparse in the Western Alps, with very low displacements to be considered in a large scale analysis (Delacou et al. 2004; Sue et al. 2007a). Despite these limitations, the interpolated velocity field appears to well correspond to the measured field (Fig. 2). The interpolated velocity field we used for strain and rotation quantifications (Fig. 3b and Fig. 4b) minimizes the neighboring velocity variations and consequently yields mean strain rates, removing the high strain rates observed on the raw GPS calculation.

\section{Results}

We present the results for both types of calculation (measured velocity and interpolated velocity fields). The calculated strain rate fields are shown in Fig. 3 and the rotation rate fields in Fig. 4. In order to better visualize the spatial variations of the calculated parameters and to provide a comparison with the seismotectonic regime, we interpolated each cell (112 cells for the raw GPS dataset, around 880 cells for the interpolated GPS dataset), using the same color code as in fig. 1. We also show the directions of maximum shortening and/or stretching in the center of each cell, on the strain rate maps (Figure 3). For reasons of clarity, only one direction is represented in the calculations based on interpolated velocities, the shortening direction for the transcurrent to compressive areas and the stretching direction for transcurrent to extensive ones.

\subsection{Strain rates}

The dilatation rates allow to discriminate between compressive and extensive areas, and therefore to compare with the regionalization of the seismotectonic deformation mode presented in Fig. 1. Nevertheless, earthquakes hypocenters are distributed over the upper crust, while GPS measurements only represent surface displacements. The elapsed time of GPS measurement being very short compared to the recurrence time of large earthquakes, the use of a seismotectonic database, which comprises only earthquakes with available focal mechanisms, can appear incomplete. However, the measurement period being of the same order for the two datasets, the observed seismological deformations should be recorded in the GPS signal. Sources of discrepancies between GPS and seismotectonics would result from aseismic deformation (see discussion in Sue et al. 2007b) or from differences in behavior between deep and surface deformations.

\subsubsection{Extensional areas}

Extensional zones (blue colors on Fig. 3) are spatially coherent on the different two approaches (raw GPS basis, Fig. 3a; interpolated GPS basis, Fig. 3b). For the alpine part, the extension is localized in three zones, corresponding to the topographic crest of the belt. In the Vanoise area, between stations RSL0 and PSBO to the West and NIV0 to the East, the direction of extension is globally oriented $\mathrm{E}-\mathrm{W}$, with a more important area to the West. This part exhibits higher values for the calculation based on raw GPS velocities (about 5-6.10-8 $\mathrm{y}^{-1}$ ) than for those

380 B. Delacou et al. 

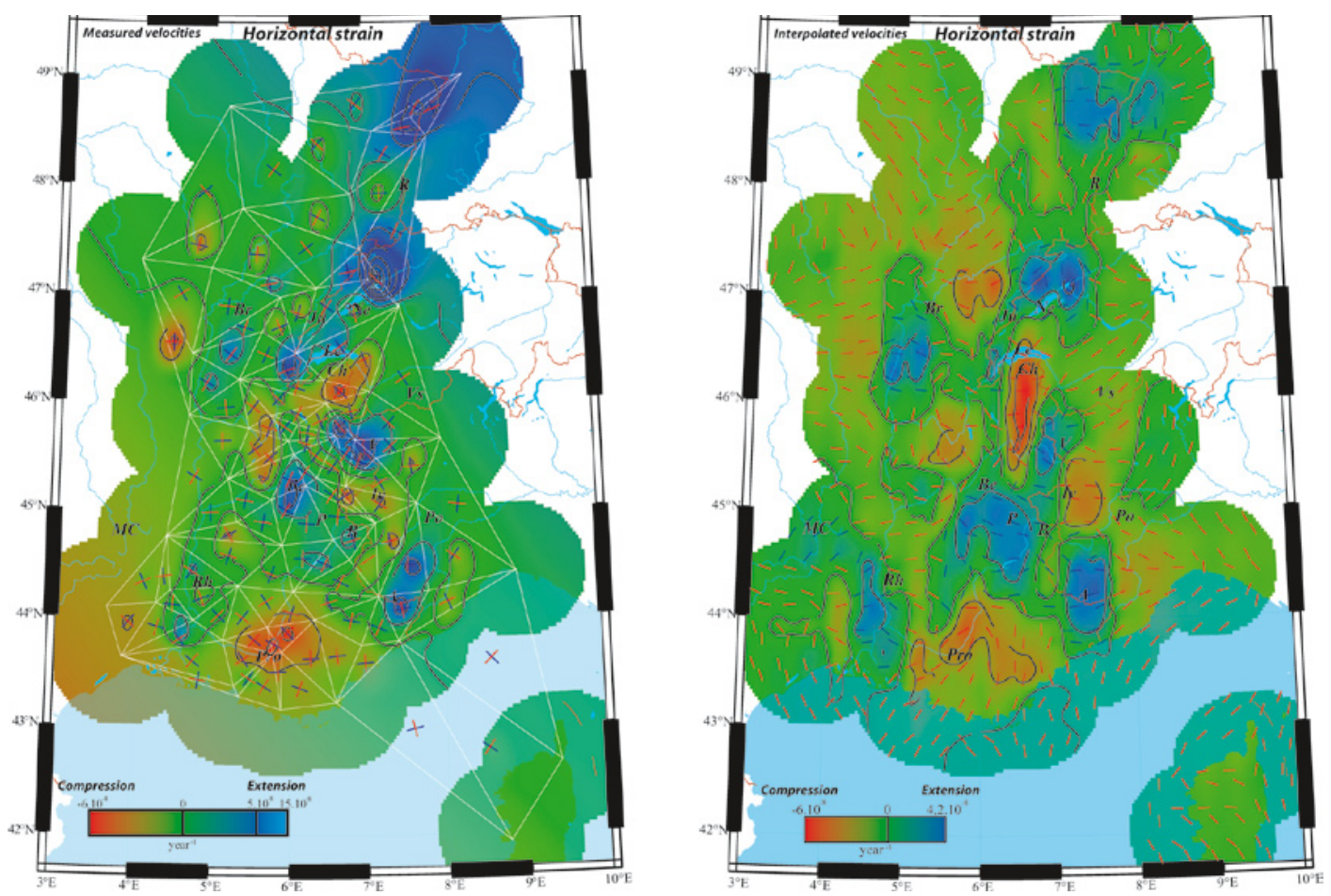

Fig. 3. Maps of the strain rate field, derived from the GPS velocity field (raw data, left, Fig. 3a) and the interpolated GPS velocity field (right, Fig. 3b). The triangular cells used in the computation are drawn on the raw velocities map. Blue colors are related to extension, and red colors to compression. Strain tensors are given by the small bars (red for shortening axes, blue for extension axes). The interpolated strain map shows the interpolated shortening axes in compression (red) or neutral (green) areas, and the interpolated extensional axes in extensional areas (blue).
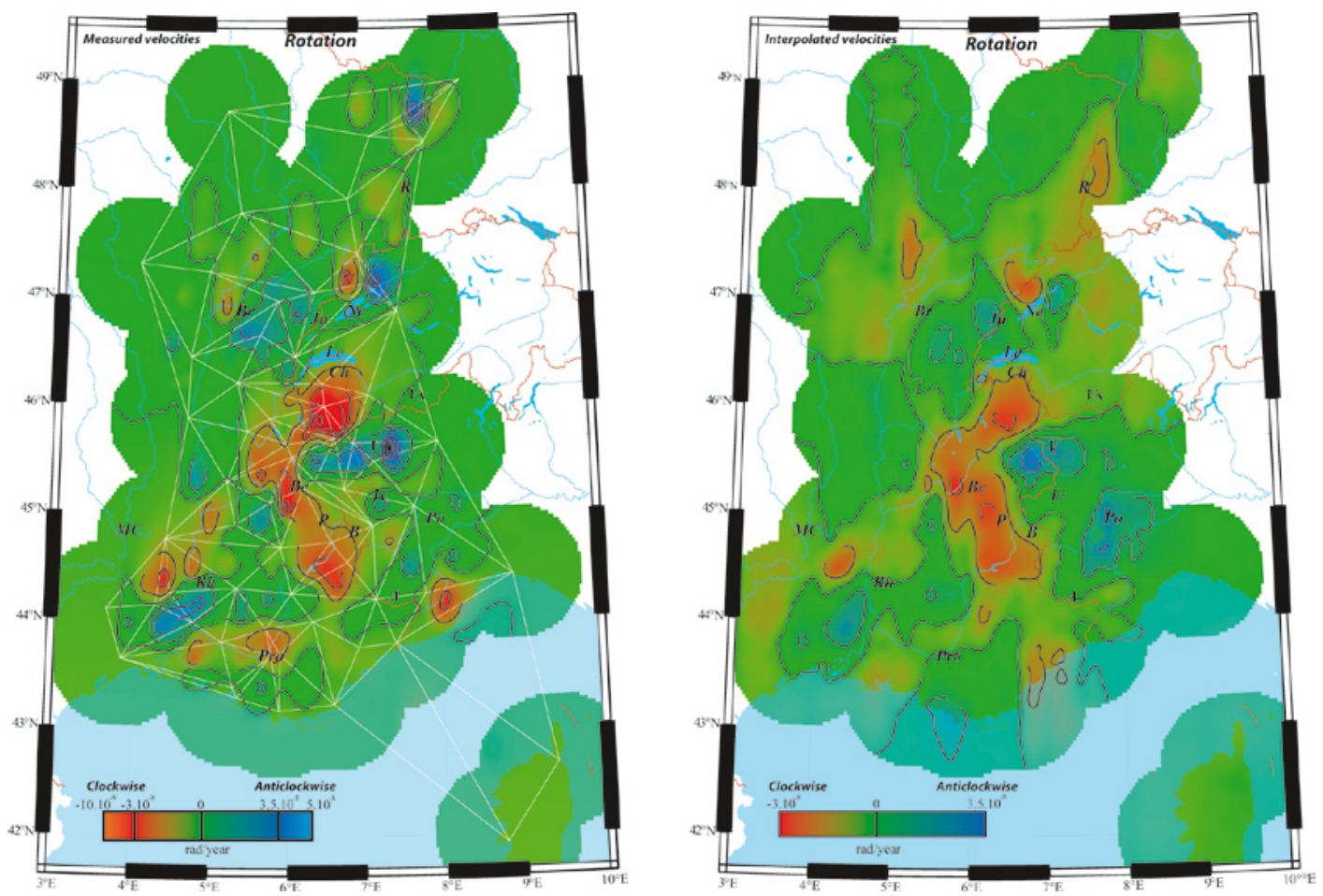

Fig. 4. Maps of the rotation rates, deduced from the GPS velocity field (raw data, left, Fig. 4a) and the interpolated GPS velocity field (right, Fig. 4b). Clockwise rotations are drawn in red, counterclockwise rotations in blue. Note the continuous arc of clockwise rotation following the outer arc of the belt. See text for details. Abbreviations: see Fig. 1. 
based on interpolated velocities (about $2-3 \cdot 10^{-8} \mathrm{y}^{-1}$ ). This zone extends towards the SSW in the Brianconnais/Pelvoux area, with almost the same direction of extension, either continuously for the raw GPS calculation (Fig. 3a) or discontinuously for the interpolated GPS calculation (Fig. 3b). Another zone of extension in the alpine domain is found in the eastern Argentera area, separated from the previous by a zone of low deformation and a spreading direction towards the N/NNE. The direction of extension in this zone is also oriented almost E-W and the calculated rates are about $2-3 \cdot 10^{-8} \mathrm{y}^{-1}$ (alike for the two techniques).

For areas located in the periphery of the belt, extension is observed in the Upper Rhine graben, with an E-W oriented direction of extension to the West and N-S to the East. In the north-eastern area of Neuchâtel lake, extension presents an unstable direction (which rapidly varies laterally). Extensional areas also appear in the Bresse plain and in the lower Rhone valley, showing an E-W to WNW-ESE direction. Maximum calculated rates are reaching $15.10^{-8} \mathrm{y}^{-1}$ in the north-eastern lake Neuchâtel area for the raw GPS based calculations, whereas the interpolation techniques provide maximum values of $4-5.10^{-8}$ $\mathrm{y}^{-1}$ in the north-eastern lake Neuchâtel area, $3-4.10^{-8} \mathrm{y}^{-1}$ in the upper Rhine graben, and 2-3.10-8 $\mathrm{y}^{-1}$ in the Bresse area and on the lower Rhone valley.

\subsubsection{Compressional areas}

Compressive areas calculated with the two techniques (Fig. 3a and $3 \mathrm{~b}$ ) are also spatially coherent on their larger trends, differences concerning their geographical extent or quantitative rates. For the Alps, compression is observed at the borders of the belt, in the southern lake Leman, with an E-W oriented direction of shortening; at the southern termination of the Jura, with a N-S to NW-SE direction; at the border of the Pô plain with a globally E-W direction; along with the Provence area with a N-S direction to the east and NE-SW to the west. The geographical distribution of compressive areas is almost identical for the two techniques, except for the southern lake Leman area where the interpolation technique spreads this compressive zone towards the south and in the Western border of the Pô plain, where the interpolation technique filter out the peaks calculated on the raw GPS basis. Maximum values of compression are found in the southern Leman lake area $\left(-4\right.$ to $\left.-6 \cdot 10^{-8} \mathrm{y}^{-1}\right)$. In the Western Pô plain, Provence, and southern Jura areas, calculated rates are lower with -2 to $-3.10^{-8} \mathrm{y}^{-1}$.

In the periphery of the belt, compression is observed in the border of the Massif Central, well-expressed with the raw GPS calculation (between stations RPE0, GRC0 and SJDV) with an E-W oriented direction and calculated rates of about $-2.10^{-8} \mathrm{y}^{-1}$. For the interpolated technique, the direction is almost identical but strain rates are almost insignificant (lesser than $-1.10^{-8}$ $\left.\mathrm{y}^{-1}\right)$. Another compressive area is found North of the Jura belt with the interpolated calculation method (strain rate of $-2.10^{-8}$ $\mathrm{y}^{-1}$ ). This area however is not found in the raw GPS calculation.
However, this also corresponds to a zone of very low strain rate, and thus directions of deformation, as well as computed strain rates are almost insignificant.

\subsection{Rotation rates}

The second calculated parameter of this study concerns angular rotation rates. As for the strain rate fields, the rotation rate fields are derived from the raw GPS velocities (Fig. 4a) and the interpolated velocities (Fig. 4b). On Fig. 4, clockwise rotations appear in red colors (negative values) and counterclockwise rotations appear in blue colours (positive values). The rotational strain rates are largely independent from the calculation technique, in terms of clockwise/anticlockwise rotation regionalization, as well as in terms of quantification.

\subsubsection{Counterclockwise rotations}

For the alpine part, counterclockwise rotations are found in the Western Pô plain area, extending in the internal zones of the orogen, as the Vanoise area, where values reach $2.10^{-8} \mathrm{rad}$. $\mathrm{y}^{-1}$ (interpolated basis) to more than $6.10^{-8}$ rad. $^{-1}$ (raw basis) maximum, in the northern part of this area (Vanoise/Ivrea Zone). A secondary peak is located to the southern (Western Pô plain), with rotation of $1.10^{-8} \mathrm{rad}^{-1}$ (raw GPS calculation) to $2.10^{-8}$ rad. $\mathrm{y}^{-1}$ (interpolated GPS calculation).

Counterclockwise rotations are inexpressive in the periphery of the belt. Areas with significant signal are located in the lower Rhone valley, showing counterclockwise rotations of about $1.10^{-8}$ rad. $y^{-1}$ (interpolated GPS basis) to $2.10^{-8} \mathrm{rad}_{\mathrm{y}} \mathrm{y}^{-1}$ (raw GPS basis); in the south-western Jura belt, with low values of about 1 to $2.10^{-8} \mathrm{rad}_{\mathrm{y}} \mathrm{y}^{-1}$; and in the north-eastern lake Neuchâtel area, with angular rotations of about $1.10^{-8} \mathrm{rad}_{\mathrm{y}} \mathrm{y}^{-1}$ (interpolated GPS basis) up to $4 \cdot 10^{-8} \mathrm{rad}^{-1}$ (raw GPS basis).

\subsubsection{Clockwise rotations}

Clockwise rotations of the alpine part of the study are located in two stripes almost perpendicular to each other (Fig.4). They create an arcuate shape, which follows the alpine bend shifted westward of the topographic crest. Counterclockwise areas situated in the Western Pô plain are located in the core of this clockwise rotating arc. This surprisingly continuous arc of clockwise rotations extends from the Chablais area to the southern termination of the Jura massif, for its northern branch, up to the Pelvoux and Brianconnais towards the Embrunnais, for its southern branch. The corresponding maxima of rotation rates varies from $-2.10^{-8} \mathrm{rad}^{-1}$ (interpolated GPS basis) to $-4.10^{-8}$ rad. $y^{-1}$ (raw GPS basis).

In the periphery of the belt, well-expressed clockwise rotations are found in the lower Rhone valley and on the north of the lake Neuchâtel, with rotations of about -1 to $-3 \cdot 10^{-8}$ rad. $\mathrm{y}^{-1}$. Less expressive clockwise rotations are observed in the Provence area and in the Ligurian sea, with rotation between -1 to $-2.10^{-8}$ rad. $y^{-1}$.

382 B. Delacou et al. 


\section{Discussion - comparison with seismotectonics}

Our geodetic strain and rotation fields may be directly compared and discussed with the seismotectonic framework of the Western Alps (Fig. 1 modified after Delacou et al. 2004). Note that the present discussion only concerns the Alpine part of the study area. We will focus our interpretations on the major trends obtained, in terms of strain and rotation fields, considering that the confidence for the GPS-related data is too low to constrain minor features. The short wavelength variations of tectonic mode (as seen in the seismotectonic regionalisation, Fig. 1) could account for the differences between the results obtained with both applied methods.

The regionalization of seismotectonic deformation (Fig. 1) shows a continuous extensional area in the core of the belt, with an orogen-perpendicular direction of extension. Smaller compressive areas are located in the periphery of the belt (in the front of the Belledonne massif, the border of the Pô plain and the front of the Digne nappe/Provence area). These characteristics are also found, with a good agreement, in the geodetic strain rate maps, with an extensional domain from the Vanoise to the Brianconnais area, but also on the external zones, in the Pelvoux and Embrunnais areas. Southward, a geodetically extensional area is found in the eastern Argentera area. It corresponds to a seismotectonic extensional area, which is continuously connected with the northern extensional areas in our seismotectonic regionalization, but not on the GPS study presented here. Maximum extensional strain rates in these zones are reaching about 3 to $6.10^{-8} \mathrm{y}^{-1}$ (higher values are found with the raw GPS basis, as the interpolation technique smoothes the velocity field). Considering the direction of extension, the GPSbased estimation also correlates with the seismotectonic regime, with a globally E-W oriented direction of extension, forming a fan from North to South, with the axes turning around with the curvature of the belt. However, the lack of GPS data in the northern part of the alpine arc (especially the Valais area), does not permit the recognition of an overall orogen-perpendicular extensional regime, as seen in the seismotectonic regionalization. Nevertheless, the good qualitative correlation between seismotectonics and geodesy in the areas well covered by GPS strengthen the orogen-perpendicular extensional character of the current tectonics in the core of the Western Alps.

The correlation with seismotectonics is also satisfactory for compressional areas, with compressive geodetic regimes in the same geographical regions of the southern Jura and the front of the Belledonne massif, the Western Pô plain area and in the front of the Digne nappe and Provence area. Maximum estimates of compression rates in these zones reach -4 to $-6.10^{-8}$ $\mathrm{y}^{-1}$. There is also a good agreement for the direction of compression with NE-SW to N-S oriented compressional axes in the Provence area (similar to seismotectonics), E-W in the Western Pô plain (NE-SW in seismotectonics) and N-S to NW$\mathrm{SE}$ in the southern termination of the Jura (E-W to NW-SE in seismotectonics). However, a major difference is found in the compressive regime seen by GPS-strain-estimates in the south-

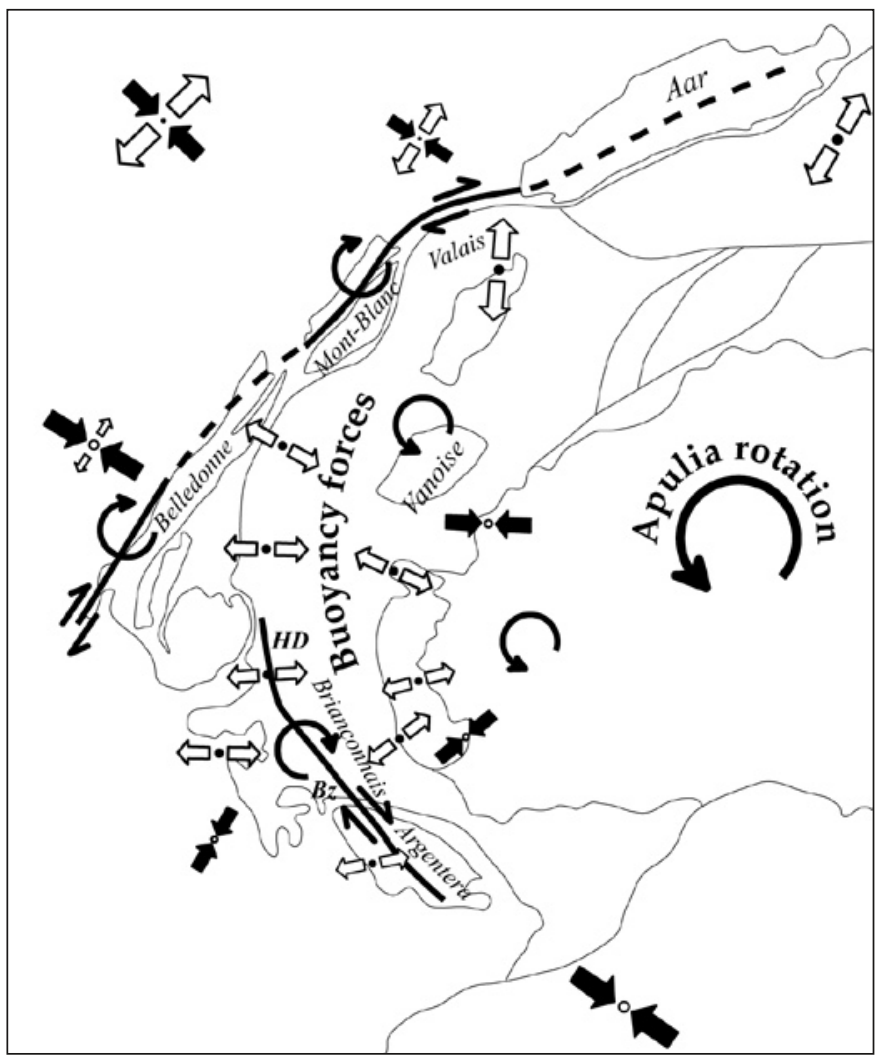

Fig. 5. Tectonic model for the Western Alps explaining the rotations observed on Fig. 4 by the counterclockwise plate rotation of Apulia, which induces clockwise block-rotations along the dextral fault system following the Western Alpine arc (Mont-Blanc/Belledonne fault system to the North, High-Durance/ Bersézio/Argentera fault system to the South). The black and white arrows give the current stress field inferred from inversion of focal mechanisms (S1 black, S3 white, after Sue et al. 1999; Delacou et al. 2004).

Abbreviations: see Fig. 1, Bz: Bersézio fault, HD: High Durance fault.

ern lake Leman area/Chablais region, which is not observed in the seismotectonic regime and which is characterized in this region by a transcurrent to extensional regime (Delacou et al. 2005a). This local issue may come from the interpolation in a zone of low constrained data, or most probably from a non-tectonic displacement of a given single GPS point such as PLJ0.

The overall strain field quantified in this study displays some contrasting results, with similar rates of compression and extension. This regime fits well with the model proposed and numerically tested by Delacou et al. (2004; 2005b) and Sue et al. (2007a) for the current geodynamics of the Western Alpine Arc. Gravitational re-equilibration of the belt due to buoyancy forces (Sue et al. 1999; Delacou et al. 2004, Sue at al. 2007a), probably enhanced by erosional processes (Champagnac et al. 2007), could account for the generalized extension in the highchain, contrasting with compressional areas at the foot of the belt.

Rotation rate computed from GPS measurements cannot be compared with seismotectonics, which doesn't bear witness of rotational strain. Nevertheless, their well-defined geograph- 
ical distribution, when compared to the geometry of the alpine arc and its tectonic architecture, leads us to propose a coherent structural interpretation. Counterclockwise rotational areas, situated in the core of the overall arcuate shape of the belt (in the Pô plain and Vanoise areas) could find their explanation in an anticlockwise Apulian rotation model, as indicated by larger scale GPS studies from Calais et al. (2002), and that has been already proposed as a main feature of the alpine dynamics (Gidon 1974; Anderson \& Jackson 1987; Ménard 1988; Vialon et al. 1989; Thomas et al. 1999; Calais et al. 2002; Collombet et al.2002). In contrast with this anticlockwise rotation, our study shows the occurrence of a large-scale arc of clockwise rotations following the curvature of the alpine arc on its Western flank. This previously unknown and unsuspected characteristic could be interpreted as an indirect expression of an overall counterclockwise boundary effect (Apulian rotation), leading to the occurrence of a general dextral transcurrent regime in the Western border of the belt, inducing clockwise rotations of crustal blocks along this fault system (Fig. 5). This transcurrent dextral fault system runs from the Aiguilles Rouges strike-slip fault, possibly connected north-eastward with the dextral seismic alignment of the northern Valais (Deichmann et al. 2002), towards the southern front of the Belledonne massif (Thouvenot et al. 2003) up to the High-Durance and Bersézio/Argentera faults Southeastward (Sue et al. 1999; Sue \& Tricart 2003).

\section{Conclusions}

We established in this paper a general and homogeneous image of deformation at the scale of the whole Western Alps, presenting a good correlation and coherency between seismotectonic and GPS related deformation. despite the large uncertainties on alpine geodetic data. Seismotectonic orogen-perpendicular extension in the high chain is well documented in our GPSstrain maps with comparable distribution and directions of extension. Equivalently, the main seismotectonic compressive areas in external zones are also found in our GPS-strain maps. Rotation rates describe a nice, continuous pattern, consistent with a model for regional kinematics influenced by the counterclockwise rotation of Apulia plate.

This study provides an attempt to quantify the geodetic strain rates, which may reach several $10^{-8} \mathrm{y}-1$. They are coherent with the routine analysis of the RENAG/CGPS sites (http:// webrenag.unice.fr), which suggests differential motion of the order of a few tenths of millimeters per year over a $50 \mathrm{~km}$ long baseline (equivalent to extension rate of $2.10^{-8} \mathrm{y}^{-1}$ ).

The proposed tectonic model to explain such features of contrasted tectonic mode and rotational strain implies a general anticlockwise rotation of Apulia plate. It induces clockwise rotations of crustal blocks along a main dextral fault system, which runs parallel to the alpine arc. In this model, gravitational re-equilibration of the orogen, enabled by null or very slow divergent boundary conditions and enhanced by erosion-related processes, account for the observed tectonic contrast.

\section{Acknowledgements}

This study was supported by the Neuchâtel University, and by the Swiss National Science Foundation (grants \# 21-61684.00, \# 200020-101625/1 and \# PA002-117441). We thank J. Martinod for his help in the calculation procedure and for fruitful discussions. We owe much to J. Mosar, G. Borel and an anonymous reviewer for their critical and constructive reviews. We are grateful to N. Stanton for many improvements in the English language. Maps have been drawn using GMT code (Wessel \& Smith 1991).

\section{REFERENCES}

Altamimi Z., Sillard, P. \& Boucher, C. 2002: ITRF2000: A new release of the International Terrestrial Reference Frame for earth science applications, Journal of Geophysical Research 107 (B10), 2214, doi:10.1029/ 2001JB000561.

Anderson, H. \& Jackson, J. 1987: Active tectonics in the Adriatic region. Geophysical Journal of Royal Astronomical Society 91, 937-983.

Baroux, E., Béthoux, N. \& Bellier, O. 2001: Analyses of the stress field in southeastern France from earthquake focal mechanisms. Geophysical Journal International 145, 336-348.

Boucher, C., Botton S. \& Duhem, L. 1995: Le Reseau de Reference Français, interface du réseau européen EUREF et du Réseau Géodésique Français (RGF). publication du LAREG, CM6, Institut Geographique National, Paris.

Boucher, C.,Altamimi,Z.\& Sillard,P.1998: Results and analysis of the ITRF96. IERS Tech. Note 24. International Earth Rotation Service., Paris, 166 pp.

Calais, E. 1999: Continuous GPS measurements across the Western Alps, 1996-1998. Geophysical Journal International 138, 221-230.

Calais, E., Bayer, R., Chéry, J., Cotton, F., Flouzat, M., Jouanne, F., Martinod, J., Mathieu, F., Scotti, O., Tardy, M. \& Vigny, C. 2000: REGAL: A permanent GPS network in the French Western Alps, Configuration and first results. Comptes Rendus Académie Sciences Paris 331, 435-442.

Calais, E., Nocquet, J. M., Jouanne, F. \& Tardy, M. 2002: Current strain regime in the Western Alps from continuous Global Positioning System measurements, 1996-2001. Geology 30, 651-654.

Caporali, A. \& Martin, S. 2000: First results from GPS measurements on present-day alpine kinematics. Journal of Geodynamics 30(1-2), 275-283.

Champagnac, J.D., Molnar, P., Anderson, R., Sue, C. \& Delacou, B. 2007: Quaternary erosion-induced isostatic rebound in the Western Alps. Geology, 35-3, 195-198. doi:10.1130/G23053A

Collombet, M., Thomas, J. C., Chauvin, A., Tricart, P., Bouillin, J. P. \& Gratier., J. P. 2002: Counterclockwise rotation of the Western Alps since the Oligocene: New insights from paleomagnetic data. Tectonics 21, 352 366.

Deichmann, N., Baer, M., Braunmiller, J., Ballarin Dolfin, D., Bay, F., Bernardi, F., Delouis, B., Fäh, D., Gerstenberger, M., Giardini, D., Huber, S., Kradolfer, M., Maraini, S., Oprsal, I., Schibler, R., Schler, T., Sellami, S., Steimen, S., Wiemer, S., Wössner, J. \& Wyss, A. 2002: Earthquake in Switzerland and surrounding region during 2001. Eclogae Geologicae Helvetiae 95, 249-261.

Delacou, B., Sue, C., Champagnac, J. D. \& Burkhard, M. 2004: Present-day geodynamics in the bend of the Western and central Alps as constrained by earthquake analysis. Geophysical Journal International 158, 753-774.

Delacou, B., Deichmann, N., Sue, C., Thouvenot, F., Champagnac, J.D. \& Burkhard, M. 2005a: Active strike-slip faulting in the Chablais area (NW Alps) from earthquake focal mechanisms and relative locations. Eclogae Geologicae Helvetiae 98, 189-199.

Delacou, B., Sue, C., Champagnac, J. D. \& Burkhard, M. 2005b: Origin of the current stress field in the Western/central Alps: role of gravitational reequilibration constrained by numerical modelling. In: Deformation, Rheology and Tectonics: from Minerals to the Lithosphere. Eds: D. Gapais, J. P. Brun and P. R. Cobbold. Geological Society, Special Publications, London, 243, 295-310.

Eva, E. \& Solarino, S. 1998: Variations of stress directions in the Western Alpine arc. Geophysical Journal International 135, 438-448.

384 B. Delacou et al. 
Gidon, M. 1974: L'arc alpin a-t-il une origine tourbillonnaire ? Comptes Rendus Académie Sciences Paris 278, 21-24.

Kastrup, U., Zoback, M. L., Deichmann, N., Evans, K. \& Giardini, D. 2004: Stress field variations in the Swiss Alps and the northern Alpine foreland derived from inversion of fault plane solutions. Journal of Geophysical Research 109(B01402).

Martinod,J.,Jouanne,F.,Taverna,J.,Ménard,G.,Gamond,J.F.,Darmendrail, X., Notter, J. C. \& Basile, C. 1996: Present-day deformation of the Dauphine (SE France) Alpine and Subalpine massifs. Geophysical Journal International 127, 189-200.

Martinod, J., Roux, L., Gamond, J. F. \& Glot, J. P. 2001: Present-day deformation of the Belledonne Massif (External Alps, France): comparison triangulation-GPS. Bulletin Société Geologique France 172(6), 713-721.

Ménard, G. 1988: Structure et cinématique d'une chaîne de collision: Les Alpes occidentales et centrales. Thèse de Doctorat d'état. Université Joseph Fourier. 278 pp., Grenoble.

Nocquet, J.M. 2002: Mesure de la déformation crustale en Europe occidentale par Géodésie spatiale. Ph.D. thesis. Univ. Nice. 307pp, Nice.

Nocquet, J.M. \& Calais, E. 2003: Crustal velocity field of Western Europe from permanent GPS array solutions, 1996-2001. Geophysical Journal International 154(1), 72-88.

Nocquet J.M. \& Calais E, 2004: Geodetic measurements of crustal deformation in the Western Mediterranean and Europe, J.-M. Nocquet, E. Calais, Pure and Apply Geophys 161(3), 661-668.

Oldow, JS., Ferranti, L., Lewis, DS., Campbell, JK., D'Argenio, B., Catalano, R., Pappone, G., CarmignaniL., ContiP. \& Aiken, C. 2002: Active fragmentation of Adria, the north African promontory, central Mediterranean orogen. Geology, 30(9), 779-782.

Serpelloni, E., Anzidei, M., Baldi, P., Casula, G., \& Galvani, A. 2005: crustal velocities and strain-rate fields in Italy and surrounding regions: new results from the analysis of permanent and non-permanent GPS networks. Geophysical Journal International 161(3), 861-880.

Sue, C., Delacou, B., Champagnac, J.D., Allanic, C., Tricart, P. \& Burkhard, M. 2007a: Extensional neotectonics around the bend of the Western/Central Alps: an overview. International Journal of Earth Sciences DOI 10.1007/ s00531-007-0181-3

Sue, C., Delacou, B., Champagnac, J.D., Allanic, C. \& Burkhard, M. 2007b: Aseismic deformation in the Alps: GPS vs. seismic strain quantification. Terra Nova, doi: 10.1111/j.1365-3121.2007.00732.x

Sue, C., Martinod, J., Tricart, P., Thouvenot, F., Gamond, J. F., Frechet, J., Marinier, D., Glot, J. P. \& Grasso, J. R. 2000: Active deformation in the inner
Western Alps inferred from comparison between 1972-classical and 1996GPS geodetic surveys. Tectonophysics 320(1), 17-29.

Sue, C., Thouvenot, F., Frechet, J. \& Tricart, P. 1999: Widespread extension in the core of the Western Alps revealed by earthquake analysis. Journal of Geophysical Research 104(B11), 25611-25622.

Sue, C. \& Tricart, P. 2003: Neogene to current normal faulting in the inner Western Alps: a major evolution of the late alpine tectonics. Tectonics 22(5).

Tesauro, M., Hollenstein, C., Egli, R., Geiger, A. \& Kahle, HG. 2005: Continuous GPS and broad-scale deformation across the Rhine graben and the Alps. International Journal of Earth Sciences 94(4), 525-537.

Thomas, J. C., Claudel, M. E., Collombet, M., Tricart, P., Chauvin, A. \& Dumont, T. 1999: First paleomagnetic data from the sedimentary cover of the French Penninic Alps: evidence for Tertiary counterclockwise rotations in the Western Alps. Earth Planetary Sciences Letter 171(4), 561-574.

Thouvenot, F., Frechet, J., Jenatton, L. \& Gamond, J. F. 2003: The Belledonne Border Fault: Identification of active seismic strike-slip fault in the Western Alps. International Journal of Earth Sciences 155(1), 174192.

Vialon, P., Rochette, P. \& Ménard, G. 1989: Indentation and rotation in the Alpine arc. In: Alpine tectonics, Geological Society of London Special Publication. Eds: M. Coward, D. Dietrich and R. Park. Blackwell scientific publication, 45, 329-338.

Vigny, C., Chery, J., Duquesnoy, T., Jouanne, F., Ammann, J., Anzidei, M., Avouac, J. P., Barlier, F., Bayer, R., Briole, P., Calais, E., Cotton, F., Duquenne, F., Feigl, K. L., Ferhat, G., Flouzat, M., Gamond, J. F., Geiger, A., Harmel, A., Kasser, M., Laplanche, M., Le Pape, M., Martinod, J., Menard, G., Meyer, B., Ruegg, J. C., Scheubel, J. M., Scotti, O. \& Vidal, G. 2002: GPS network monitors the Western Alps deformation over a five- year period: 1993-1998. Journal of Geodesy 76(2), 63-76.

Walpersdorf, A., Baize, S., calais, E., Tregoning, P. \& Nocquet, J.M. 2006: Deformation in the Jura Mountains (France): First results from semi-permanent GPS measurements. Earth Planetary Sciences Letter (245), 365-372.

Wessel, P. \& Smith, WH. 1991: Free software heps map and display data. EOS Trans. AM. Geophys. Union, 72:441 and 445-446.

Manuscript received October 17, 2007

Revision accepted May 7, 2008

Published Online first July 31, 2008

Editorial Handling: Jon Mosar, Stefan Bucher 